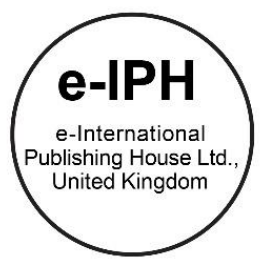

\title{
Introducing a Method for Social-ecological Assessment of Small Urban Parks
}

\author{
Zanariah Jasmani1 ${ }^{1}{ }^{*}$, Hans Peter Ravn¹, Cecil C. Konijnendijk van den Bosch ${ }^{3}$ \\ ${ }^{1}$ Department of Geosciences and Natural Resource Management, Faculty of Science, University of Copenhagen, Frederiksberg C, Denmark \\ 2Department of Landscape Architecture, Faculty of Built Environment, Universiti Teknologi Malaysia, Skudai, Johor, Malaysia \\ ${ }^{3}$ Department of Landscape Architecture, Planning and Management, Swedish University of Agricultural Sciences, Alnarp, Sweden
}

\begin{abstract}
Small parks in cities are important to support overall urban biodiversity and ecological network. The aim of this paper is to introduce a method of identifying and assessing the ecological characteristics and anthropogenic factors of small urban parks. We developed a framework that combined structured observation and field measurement. The method suggests an integrative assessment that is practical and understandable to the park planners and managers to enhance small parks to support overall urban biodiversity and ecosystem services. High biodiversity can provide opportunities for humans to experience nature and wildlife in cities, thus contributing to the quality of life of urban dwellers.

(C) 2016. The Authors. Published for AMER ABRA by e-International Publishing House, Ltd., UK. Peer-review under responsibility of AMER (Association of Malaysian Environment-Behaviour Researchers), ABRA (Association of Behavioural Researchers on Asians) and cE-Bs (Centre for Environment-Behaviour Studies), Faculty of Architecture, Planning \& Surveying, Universiti Teknologi MARA, Malaysia.
\end{abstract}

Keywords: ecological resilience; urban parks; vegetation diversity; human impact

\section{Introduction}

Urban development can put pressure on the urban green spaces which as a consequence can become smaller and fragmented. Small parks can enhance the quality of urban life by providing opportunities for people to experience nature and wildlife in cities. The study presented here is part of a broader research project that investigates ecological resilience of, and human impact on small urban parks, and their implications for park design, planning and management. The purpose of this paper is to introduce a method for integrative evaluation of ecological and anthropogenic (human related) characteristics of small urban parks. By applying the method, the capability of small urban parks to support urban biodiversity and ecological functions are explored, as is the impact of human interaction.

Small urban parks, often referred to as pocket parks (Peschardt, Stigsdotter, \& Schipperrijn, 2014) can comprise a range of outdoor public areas, including grey spaces (such as small squares, paved areas) and green spaces, and with vegetation ranging from trees to lawns and flower beds (Nordh, Alalouch, \& Hartig, 2011). For the purpose of this study, we defined small urban parks as small-scale urban green spaces with the sizes between 0.5 to 3.5 hectares, have a well-defined boundary and

\footnotetext{
${ }^{*}$ Corresponding author. Tel.: +4550319445; fax: +0-000-000-0000 .

E-mail address: zbj@ign.ku.dk, zanariahj@utm.my
}

(c) 2016. The Authors. Published for AMER ABRA by e-International Publishing House, Ltd., UK. Peer-review under responsibility of AMER (Association of Malaysian Environment-Behaviour Researchers), ABRA (Association of Behavioural Researchers on Asians) and cE-Bs (Centre for Environment-Behaviour Studies), Faculty of Architecture, Planning \& Surveying, Universiti Teknologi MARA,Malaysia.

DOI: https://doi.org/10.21834/e-bpj.v1i2.277 
provide opportunities for public recreation. The proposed method should help answer the question how human factors influence biodiversity and ecological functionality in order to provide a better base for decision making in design, planning and management of small urban parks. Small urban parks provide an essential, but sometimes overlooked component of urban green infrastructure (Peschardt et al., 2014). Most previous research that relates urban parks, biodiversity and ecosystem services were focused on large size parks (Idilfitri \& Mohamad, 2012; Nielsen, van den Bosch, Maruthaveeran, \& van den Bosch, 2013). Many of ecosystem services in urban areas depend on the species present in different green areas (e.g. urban parks), and these services can contribute to human well-being (Niemelä, 2014). Small urban parks have been found to provide psychological benefits and act as restorative environments (Nordh et al., 2011) while they also enhance social cohesion (Peschardt et al., 2014).

In this study, we adopted the resilience approach as the foundation for evaluating small urban parks as social-ecological systems. The resilience concept in ecology emerged in the early 1970s (Holling, 1996) and had been described as a way of thinking to analyse the social-ecological component of urban spatial planning and design (Colding, 2007). One of the strategies to build urban resilience capacity is through biodiversity conservation. Enhancing resilience requires the collaboration of scientists, planners, designers and policy makers (Ahern, 2013).

\section{The Assessment Method}

When planning and managing small urban parks, it is important to understand how to balance social and ecological needs. Past research on the evaluation of small urban parks has been very much focused on social (human) aspects and typically embodied shallow discussion on the ecological factors (related to nature and biodiversity) (Nordh \& Østby, 2013). This paper presents an integrative assessment method that applies to the design, planning and management of small urban parks. The method combines structured observation and field measurements. Structured observation is a systematic method of data collection that has been primarily used in social and behavioural science (Phellas, Bloch, \& Seale, 2011), education and public health (Madigan et al., 2014). In an ecological context, it is sometimes referred to as naturalistic observation because it involves observing human or animal behaviour in their natural habitats (Jackson, 2014). Naturalistic observation is an essential ecological approach for identifying animal species variables (Johnston \& Pietrewicz, 2014), and it has greater ecological validity as compared to other methods (Jackson, 2014). In this study, we used structured observation to assess human activities, animal species richness, soundscapes and smells. Field measurements were used to measure the features and landscape elements in the parks, vegetation diversity and structure, as well as noise levels (decibels). Jointly, structured observation and field measurements have been used as part of an integrative framework to study the socio-ecological characteristics of small urban parks.

\subsection{Field survey}

We developed a framework to investigate small urban parks in the city of Petaling Jaya, Selangor, Malaysia (Table 1). The framework was developed based on the literature and inspired by the work of, for example, Nagendra \& Gopal (2011), Ostermann (2010), Rune \& Hels (2004), and Tzoulas \& James (2010). Before conducting field surveys, it is important to have the background and initial information about the parks. This information can be achieved by utilising aerial photos from satellite imagery or other sources, and by referring to information provided by the municipality. Satellite imagery is a very useful tool in providing broad spatial data on, e.g., land cover, vegetation information, built structure and land mapping (Morgan, Gergel, \& Coops, 2010). The studied parks were chosen based on the criteria of size, location and function. The size of the parks is between 0.5 to 3.5 hectares and all parks are publicly accessible. This study excludes private parks and parks that were specially designed for a certain activity, such as a skateboard park, because such parks are considered less representing for small urban parks due to limitations of use and users.

The field survey was conducted in nine small urban parks in August and September 2014. Observations in the parks were carried out for three consecutive working days for two hours each in the morning (7.30 - $9.30 \mathrm{hrs}$ ), afternoon (12.30 - $14.30 \mathrm{hrs})$ and evening (17.00 - $19.00 \mathrm{hrs})$. The reason for scheduling the observations three times a day for three days was to obtain an accurate estimation of the condition of the park that will vary with time while still limited the number of measurements (Cohen et al., 2013). The chosen times also represent the peak in the number of visitors and traffic intensity in the roads surrounding the parks. 
Table 1. Framework for identifying and assessing ecological components and anthropogenic factors in small urban parks

\begin{tabular}{|c|c|c|c|c|c|}
\hline Category & Variables & Sub-variables & $\begin{array}{l}\text { Survey } \\
\text { method }\end{array}$ & Method description & $\begin{array}{l}\text { Survey period } \\
-3 \text { days }\end{array}$ \\
\hline Ecological & $\begin{array}{l}\text { Physical } \\
\text { characteristics }\end{array}$ & $\begin{array}{l}\text { Topography } \\
\text { Temperature } \\
\text { Water element } \\
\text { Special conditions }\end{array}$ & $\begin{array}{l}\text { FM \& } \\
\text { SO }\end{array}$ & $\begin{array}{l}\text { Check relevant information from secondary } \\
\text { sources (maps, etc.) } \\
\text { Observe and verify the secondary } \\
\text { information on-site and records for any } \\
\text { occasional or temporary condition }\end{array}$ & $\begin{array}{l}\text { Once } \\
\text { throughout } \\
\text { the survey } \\
\text { period }\end{array}$ \\
\hline Anthropogenic & & $\begin{array}{l}\text { Land use } \\
\text { Size, shape, perimeter } \\
\text { Site context } \\
\text { Accessibility } \\
\text { Proximity to road and } \\
\text { infrastructure } \\
\text { Building and facilities } \\
\text { Special conditions }\end{array}$ & $\begin{array}{l}\text { FM \& } \\
\text { SO }\end{array}$ & $\begin{array}{l}\text { Check relevant information from secondary } \\
\text { sources (maps, etc.) } \\
\text { Observe and verify the secondary } \\
\text { information on the site } \\
\text { Measure fixed structure on site, e.g. } \\
\text { pathway, shelter, etc. (only those relevant) } \\
\text { Observe and record any occasional or } \\
\text { temporary condition }\end{array}$ & $\begin{array}{l}\text { Once } \\
\text { throughout } \\
\text { the survey } \\
\text { period }\end{array}$ \\
\hline \multirow[t]{2}{*}{ Ecological } & $\begin{array}{l}\text { Species } \\
\text { richness }\end{array}$ & $\begin{array}{l}\text { Vegetation diversity } \\
\text { and structure }\end{array}$ & FM & $\begin{array}{l}\text { Count the abundance of all vegetation } \\
\text { (trees, shrubs, palms, groundcover } \\
\text { vegetation, etc.) } \\
\text { Identify the species name (local \& scientific } \\
\text { name) } \\
\text { Measure the height, trunk diameter \& tree } \\
\text { canopy size }\end{array}$ & $\begin{array}{l}\text { Once } \\
\text { throughout } \\
\text { the survey } \\
\text { period }\end{array}$ \\
\hline & & Birds and butterflies & so & $\begin{array}{l}\text { Observe using binoculars and take } \\
\text { photographs with a high-resolution digital } \\
\text { camera } \\
\text { Identify the local \& scientific name using } \\
\text { species identification guidebook }\end{array}$ & 3 times a day \\
\hline \multirow[t]{5}{*}{ Anthropogenic } & Human factors & Human activities & so & $\begin{array}{l}\text { Observe people's activities and record in } \\
\text { the survey form } \\
\text { Observe \& describe human misbehaviour } \\
\text { towards natural resources (if any) }\end{array}$ & 3 times a day \\
\hline & & $\begin{array}{l}\text { User density (number } \\
\text { of visitors) }\end{array}$ & $\begin{array}{l}\text { FM \& } \\
\text { SO }\end{array}$ & $\begin{array}{l}\text { Count the number of visitors according to } \\
\text { two groups: passersby and park users }\end{array}$ & 3 times a day \\
\hline & & $\begin{array}{l}\text { Soundscapes } \\
\text { Sound levels (dB) }\end{array}$ & FM & $\begin{array}{l}\text { Measure the level of decibel }(\mathrm{dB}) \text { using the } \\
\text { sound level meter at three different spots. At } \\
\text { each spot, record } 10 \text { readings with the } \\
\text { intervals of } 3 \text { minutes }\end{array}$ & 3 times a day \\
\hline & & Sound diversity & so & $\begin{array}{l}\text { Identify the types of the sound according to } \\
\text { two groups: natural and anthropogenic } \\
\text { sound }\end{array}$ & 3 times a day \\
\hline & & Smells & so & $\begin{array}{l}\text { Identify the types of smells according to two } \\
\text { groups: pleasant and unpleasant }\end{array}$ & 3 times a day \\
\hline
\end{tabular}

FM= Field measurement, $\mathrm{SO}=$ Structured observation 


\subsection{Variables measured}

In the presented framework (Table 1), we categorised the data broadly into two categories: ecological and anthropogenic. The variables were divided into three main data sets: physical characteristics, species richness and human factors.

\subsubsection{Physical characteristics}

The characteristics of the parks are important for analysing the spatial information, physical quality, and they may have a significant impact on the ecological functions (Ren et al., 2013). Information that is needed includes data on surrounding landuse, topography, size, shape, context (proximity to road and infrastructure), building and facilities, and the presence of water elements. Topographic information can be essential, especially for parks that include elevation differences. The size, shape and perimeter may describe the edge effect of the urban park. Besides, information on land use, site context, building and facilities can help to characterise the socioeconomic patterns of the area.

\subsubsection{Species richness}

The data sets for species richness include both plants and animals. Identification of all vegetation (trees, palms, shrubs, groundcover, etc.) in urban parks is necessary to study the distribution of native and exotic, habitat diversity and flora-fauna relationships (Nielsen et al., 2013). The structure (diameter, height and tree canopy size) of big and matured vegetation was measured. Data on vegetation structure and composition is necessary because these may influence the fauna species diversity (Hunter, 2011), as well as differences in sound levels and soundscape experience (Irvine et al., 2009). Vegetation structure and composition can also impact the thermal comfort experienced by park users (Ren et al., 2013). An appropriate mixed of vegetation can support biodiversity and maximises ecosystem services (Nagendra \& Gopal, 2011).

Here the study of animals was limited to birds and butterflies since these are relatively conspicuous and fairly easy to survey. Moreover, birds and butterflies are highly sensitive to habitat disturbance which makes them into good indicators for assessing habitat quality and environmental change (Peris \& Montelongo, 2014; Sandström, Angelstam, \& Mikusiński, 2006). We used 40 $\mathrm{m}$ to $50 \mathrm{~m}$ radius point counts (three points in each park) to survey the presence of bird species. Besides, line transects were used to observe butterflies. For identifying each species, pictures of birds and butterflies were captured by using a highresolution digital camera. Then, to confirm their species name, we used a guide book for identification of the birds and butterflies in Malaysia from Davidson \& Aik (2010) and Kirton (2014). In the results section, as an illustration of how the method can be implemented, we present and discuss findings for bird species only.

\subsubsection{Human factors}

Observation of human factors includes activities, user density, soundscapes and smells. Observation of the human activities in the park and the surrounding area was done structurally based on the classification by Tzoulas \& James (2010) who group activities in urban parks into four categories; utilitarian, recreation, sport and play. We added one more group, namely special occasions in recognition of activities that occasionally happen in parks, such as ceremonies, photo shooting, team building and events. Potential activities are listed beforehand according to these five groups and during the observation time, observers have to choose which activities occur in the park. Activities outside the park and the nearby area were described briefly in the survey form.

Visitors count. Since the parks are small in size and visually accessible from all angles, only one or two observers were needed to count the number of visitors to the park (Arnberger, Haider, \& Brandenburg, 2005). Visitors were divided into two categories; park users and passersby. For this study, park users are defined as peoples who uses the park as a destination and spends a minimum of 15 minutes for their activities, while passersby are defined as persons who uses the park as a pathway to other places. The number of park users (as related to the park area) indicates how intensive the park is being used (Arnberger et al., 2005).

Soundscapes. The soundscape of urban parks can be quite complex as it comprises a combination of many different types of sound (Tse et al., 2012). In this study, we defined the soundscape as the level of sound measured in decibel ( $d B$ ) and the diversity of sound (types of sounds). The evaluation of sound levels and sound diversity is essential as it may influence recreational use as well as the richness of animal species especially in the small urban parks (Carbo-Ramirez \& Zuria, 2011). The measurements of the sound levels were carried out at three designated spots in the parks (at the same spot used for bird 
survey). The measurement spots were located in the area most used by the park visitors, as closely as possible to the sound sources and at a distance of approximately less than 100 metres from each other. The equipment for measuring sound levels was placed firmly approximately 1.5 metres above ground. At each spot, the observers recorded the noise levels for ten times at intervals of three minutes. The diversity of sounds was divided into two classes: natural and anthropogenic or mechanical. Natural sounds include, e.g., bird chirping, a rustling of leaves, etc., whereas anthropogenic or mechanical sounds refer to all sounds made by humans. All sound types that can be heard in the park are listed according to the respective category.

Smells. The 'smellscapes' can be an important part of the urban sensory experience (Henshaw, 2014). In urban parks, smells can relate to air quality and recreational value (McCormack, Rock, Toohey, \& Hignell, 2010). However, studies on smell experience and its relation to ecological characteristics and human behaviour in urban parks have been limited to date. In this study, we classified the types of smells into pleasant or unpleasant. At the same spots where the bird survey and soundscape measurement were carried out, the observer also had to experience the smells that occur in the park.

\subsection{Analysis}

All data that was recorded during the field work was compiled into a table format using Microsoft Excel $($ Professional Plus 2010. The information was arranged and extracted from a larger set by using the pivot table function and matrix table. The tables were used for cross tabulation to analyse the relationships and to compare the results between variables. We conducted Pearson correlations in $\mathrm{R}$ version 3.1.2 to examine the relationships among the parameters of physical characteristics, species richness and human factors.

\section{Results}

As an illustration of how the assessment method can be implemented, we present some of the findings from the case study of small urban parks in Petaling Jaya. A total of 89 different plant species (trees, palms and shrubs) and 22 bird species were observed in the parks. Exotic vegetation species were planted more than native species (Table 2). The most popular tree species used as an ornamental plant is Tabebuia rosea (Trumpet Tree). Veitchia merrillii (Christmas Palm) is the common palm species planted and Hymenocallis speciosa (Spider Lily) is frequently used as an ornamental shrub. The birds found in the parks are mostly insectivores (feed only insects) and omnivores (feed both plants and small animal). The most abundance bird species is Passer montanus (Eurasian Tree-sparrow), followed by Copsychus saularis (Oriental Magpie-robin) and Corvus splendens (House Crow). Most of the birds are generalist species and urban adapters. We also observed the common Little Heron (Butorides striata) in the park that has a lake. The occurrence of passage migrant bird (Merops viridis (Blue-throated Bee-eater)) was also noted. Merops viridis is a seasonal breeder of Peninsular Malaysia in April to September and then migrates to Sumatra afterwards (Nisbet, 2013). The bird of prey (Accipiter trivirgatus (Crested Goshawk)) was also observed perched on a branch with dense foliages.

Observation of user activities demonstrated that the parks were used more for utilitarian purposes $(42 \%$, e.g. as walking or motorcyclist access) than for recreation (32\%, e.g. relaxing or family outing) or sports, play and special occasions such as celebrations (26\%) (Fig. 1a). In relation to sound, we experienced more anthropogenic sounds than natural ones (Fig.1b). Moreover, we also experienced more unpleasant than pleasant smells from vehicles, animal manure, food waste, garbage and drains. 
Table 2. Summary of vegetation and bird species characteristics of each studied park

\begin{tabular}{lllllllllll}
\hline Park & $\begin{array}{l}\text { Size } \\
\text { (ha) }\end{array}$ & $\begin{array}{l}\text { Total } \\
\text { vegetation }\end{array}$ & $\begin{array}{l}\text { Vegetation } \\
\text { species } \\
\text { (NOS) }\end{array}$ & $\begin{array}{l}\text { Canopy } \\
\text { covers } \\
(\%)\end{array}$ & $\begin{array}{l}\text { Native } \\
\text { vegetation } \\
\text { (NOI) }\end{array}$ & $\begin{array}{l}\text { Exotic } \\
\text { vegetation } \\
\text { (NOI) }\end{array}$ & $\begin{array}{l}\text { Native } \\
\text { vegetation } \\
\text { species } \\
\text { (NOS) }\end{array}$ & $\begin{array}{l}\text { Exotic } \\
\text { vegetation } \\
\text { species } \\
\text { (NOS) }\end{array}$ & $\begin{array}{l}\text { Bird } \\
\text { species } \\
\text { (NOS) }\end{array}$ & $\begin{array}{l}\text { Bird } \\
\text { abundance } \\
\text { (ave./day) }\end{array}$ \\
\hline 1 & 0.7 & 424 & 32 & 76 & 96 & 328 & 9 & 22 & 9 & 27 \\
2 & 0.7 & 90 & 12 & 77 & 56 & 34 & 6 & 5 & 8 & 34 \\
3 & 0.7 & 74 & 10 & 34 & 21 & 53 & 2 & 7 & 16 & 65 \\
4 & 1 & 103 & 10 & 53 & 45 & 58 & 4 & 6 & 8 & 43 \\
5 & 1 & 59 & 11 & 48 & 6 & 53 & 3 & 7 & 15 & 65 \\
6 & 1.2 & 82 & 8 & 90 & 34 & 48 & 2 & 5 & 7 & 20 \\
7 & 1.5 & 54 & 7 & 68 & 15 & 39 & 2 & 4 & 10 & 30 \\
8 & 2.5 & 354 & 26 & 53 & 145 & 209 & 10 & 15 & 19 & 71 \\
9 & 3.5 & 381 & 52 & 67 & 157 & 155 & 27 & 24 & 15 & 63 \\
\hline
\end{tabular}

NOI: Number of individuals, NOS: Number of species. Bird abundance was calculated based on the frequency scale of 1-very low to 10very high.

Table 3. Summary of park physical characteristics and human factors

\begin{tabular}{|c|c|c|c|c|c|c|c|c|c|}
\hline \multirow[t]{2}{*}{ Park } & \multirow[t]{2}{*}{ Shape } & \multirow[t]{2}{*}{ Surrounding land use } & \multirow{2}{*}{$\begin{array}{l}\text { Proximity to the } \\
\text { main road }\end{array}$} & \multirow{2}{*}{$\begin{array}{l}\text { Water } \\
\text { body }\end{array}$} & \multirow{2}{*}{$\begin{array}{l}\text { Nr. of } \\
\text { visitor } \\
\text { (n/day) }\end{array}$} & \multicolumn{3}{|c|}{ Num. of activities } & \multirow{2}{*}{$\begin{array}{l}\text { Sound } \\
\text { levels } \\
\text { (dB/day) }\end{array}$} \\
\hline & & & & & & Mor. & Aft. & Eve. & \\
\hline 1 & Irregular & Com., Inst.,Res & $<30 \mathrm{~m}$ & Non & 200 & 12 & 14 & 8 & 77 \\
\hline 2 & Linear & Com., Inst., Res., Ind. & $<25 \mathrm{~m}$ & Non & 514 & 42 & 42 & 47 & 81 \\
\hline 3 & Triangular & Com., Res., Inst. & $<30 \mathrm{~m}$ & Non & 115 & 43 & 21 & 36 & 72 \\
\hline 4 & Irregular & Res. Com., Inst. & $<100 \mathrm{~m}$ & Non & 106 & 32 & 18 & 45 & 63 \\
\hline 5 & Triangular & Res., Com., Inst. & $<150 \mathrm{~m}$ & Non & 81 & 46 & 19 & 30 & 60 \\
\hline 6 & Square & Res., Ind., Com., Inst. & $<200 \mathrm{~m}$ & Non & 133 & 29 & 33 & 45 & 58 \\
\hline 7 & Square & Com., Res., Inst. & $<70 \mathrm{~m}$ & Non & 501 & 41 & 32 & 38 & 71 \\
\hline 8 & Square & Res., Com., Inst. & $<70 \mathrm{~m}$ & Lake & 369 & 46 & 44 & 58 & 66 \\
\hline 9 & Irregular & Res., Com., Inst & $>50 m<200 m$ & Lake & 456 & 49 & 38 & 51 & 68 \\
\hline
\end{tabular}

Com: Commercial, Inst: Institutional, Res: Residential, Ind: Industrial, Nr: Number, Mor.: Morning, Aft:: Afternoon, Eve: Evening

(a) Activities patterns

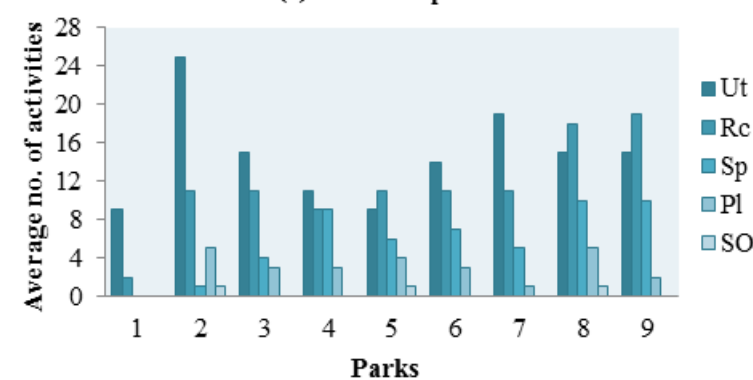

(b) Sound Diversity

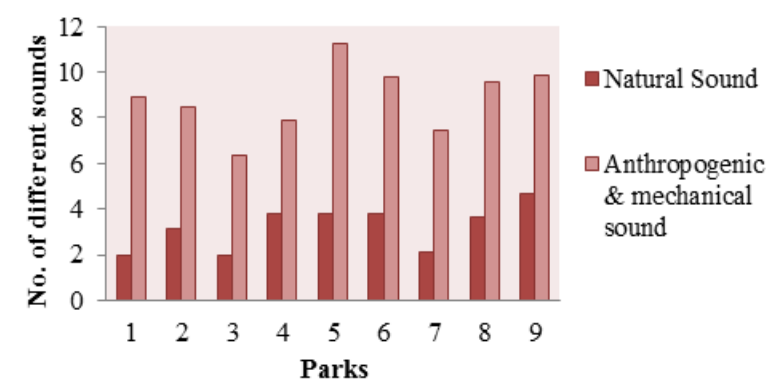

Fig. 1. (a) The pattern of human activities in the parks.Ut: utilitarian, Rc: recreation, Sp: sports, SO: special occasion; (b) The sound diversity in the parks 
Table 4. Relationships between the park variables with the number of bird species present in the parks and their abundance

\begin{tabular}{llllllllllll}
\hline & \% Can. & Nat.veg & $\begin{array}{l}\text { Exo.ve } \\
\mathrm{g}\end{array}$ & $\begin{array}{l}\text { Nat.sp } \\
\mathrm{p}\end{array}$ & $\begin{array}{l}\text { Exo.sp } \\
\mathrm{p}\end{array}$ & Tr.hgt & $\begin{array}{l}\text { Can. } \\
\text { Size }\end{array}$ & $\begin{array}{l}\text { Sh.hgt } \\
\text { Vis. } \\
\text { num }\end{array}$ & Noi. lev & Util. \\
\hline $\begin{array}{l}\text { Bird species } \\
\text { richness }\end{array}$ & $-0.692^{*}$ & 0.387 & 0.207 & 0.338 & 0.340 & -0.558 & -0.540 & 0.472 & 0.028 & -0.137 & -0.155 \\
$\begin{array}{l}\text { Birds } \\
\text { abundance }\end{array}$ & $-0.803^{* *}$ & 0.318 & 0.047 & 0.347 & 0.246 & -0.557 & -0.585 & 0.612 & -0.075 & -0.190 & $-0.182^{*}$ \\
\hline
\end{tabular}

${ }^{*} p<0.05,{ }^{* *} p<0.01, \%$ Can: Percentage of canopy covers, Nat. veg: Native vegetation, Exo.veg: Exotic vegetation, Nat spp: Native species, Exo. spp: Exotic species, Tr.hgt: Tree height, Can.size: Canopy size, Sh.hgt: Shrub height, Vis. num: Visitors number, Noi.lev: Noise levels, Util: Utilitarian use

As an example of more in-depth analysis, Pearson correlations were performed to identify those variables that influence bird species richness and abundance (Table 4). Results show that bird abundance has a strong negative relation with the percentage of canopy cover. Results also indicate that the presence of both native and exotic vegetation has a positive relation to bird species richness, whereas tree height and canopy size were found to have a negative correlation with bird species richness and abundance. That is not unexpected, as the taller the tree and larger the canopy, the fewer bird species could be seen by the observers, although bird species richness and abundance will probably be higher than observed. Birds favoured tall shrubs, presumably because these provide them with more food sources like seeds, nectar and some invertebrates.

Utilitarian human uses were found to have a weak negative correlation with bird abundance. Other types of human activities did not have an adverse influence on the presence of bird species. The number of visitors and noise levels might have a negative impact on the bird abundance, but in this study, the effect was minimal.

\section{Discussion and Conclusions}

Findings from the case study in Malaysia suggest that the mixed use of native and exotic vegetation in small urban parks may increase the number of bird species and abundance. However, this might be true only for small parks, and as for larger parks more native plants are preferred (Mohamad, Idifitri, \& Thani, 2013). Some exotic vegetation also provides food resources and shelter for urban birds (Sulaiman, Mohamad, \& Idiffitri, 2013). The study's results indicate that the human activities in the parks did not affect bird species richness and abundance. Perhaps the intensity of park use was not that heavy in the parks studied, or human activities only had a minor influence compared to other variables. However, through the study's observations revealed that some people use the parks as a place for relaxing while enjoying their food. Food wastes if not disposed of properly can create littering problems and attract unwanted scavenging birds like House Crows. When small parks were located near garbage collection sites, many House Crow were present and even nested in the parks. The abundance of House Crow may threaten small native birds through nest exploitation or food source competition (Chace \& Walsh, 2006).

Based on the data gathered and results obtained from the case study, the strengths and weaknesses of the method can be discussed. Bird surveys can be challenging as birds are very active, and observers need to recognise as many details as possible in a short timespan. However, due to the open vegetation and high visibility within most of our sites, we felt confident that our methods allowed us to detect most bird species present in the parks. It can be debated whether limiting observations of animal species to only birds and butterflies suffice. Further research on other species group such as mammals could provide more understanding of the overall species richness of small urban parks.

When identifying human activities, the structured observation method allowed us to assess actual behaviour rather than relying on interviews and surveys. Although observations may reveal human activity patterns in small parks, they cannot disclose the reasons for why these activities are preferred over other activities. Observer interpretation of activities sometimes can be difficult, and can be biased based on familiar events. Therefore, to minimise bias, it is important for the observer to be clear with the study objectives, observation coding and survey protocols. Another important consideration while conducting structured observation is reactivity, which means a response from the subject, especially human when they realise that they are being observed. Apart from observation, future research can incorporate interviews and questionnaires to broaden the evidence base on visitor experience of ecosystem services in small urban parks. The proposed method can be applied to the assessment of small urban parks in different locations, and especially in situations where resources and time for data collection are limited. 
However, few modifications might be needed, e.g., for densely vegetated and larger size parks, more than two observers are perhaps required due to the visibility limitation.

Since urban areas will continue to expand and probably also densify in the future, assessment of biodiversity and ecological functions of small parks becomes increasingly important. In efforts of building green and more sustainable cities, small parks can play a role in supporting overall urban biodiversity, ecosystem services, ecological networks, and creating a healthier environment for urban citizens, especially in areas where larger parks are absent. The design of small parks should address both ecological functions and socio-cultural ones in the built environment. Collaboration among professionals in landscape architecture, urban ecology, green space management and town planning will be essential for planning, designing and managing urban green spaces that support human well-being in a healthy urban ecosystem.

\section{Acknowledgements}

This paper is part of a PhD study entitled 'Ecological Resilience of Small Urban Parks: System Functionality and Adaptation to Disturbances' at the Department of Geosciences and Natural Resource Management, University of Copenhagen. The authors gratefully acknowledge the Ministry of Higher Education, Malaysia and Universiti Teknologi Malaysia for funding and financial support. We would also like to thank all of the assistants for their help in conducting the field survey in Malaysia.

\section{References}

Ahern, J. (2013). Urban landscape sustainability and resilience: The promise and challenges of integrating ecology with urban planning and design. Landscape Ecology, 28, 1203-1212.

Arnberger, A., Haider, W., \& Brandenburg, C. (2005). Evaluating visitor-monitoring techniques: a comparison of counting and video observation data. Environmental Management, 36, 317-27.

Carbo-Ramirez, P., \& Zuria, I. (2011). The value of small urban greenspaces for birds in a Mexican city. Landscape and Urban Planning.

Chace, J. F., \& Walsh, J. J. (2006). Urban effects on native avifauna: A review. Landscape and Urban Planning, 74, 46-69.

Cohen, D. A., Setodji, C., Evenson, K. R., Ward, P., Lapham, S., Hillier, A., \& McKenzie, T. L. (2013). How much observation is enough? Refining the administration of SOPARC. Journal of Physical Act Health, 29, 997-1003.

Colding, J. (2007). "Ecological land-use complementation" for building resilience in urban ecosystems. Landscape and Urban Planning, 81, 46-55.

Henshaw, V. (2014). Urban Smellscapes: Understanding and designing city smell environment. New York: Routledge.

Holling, C. S. (1996). Engineering resilience versus ecological resilience. Engineering within Ecological Constraints, 31-43.

Hunter, M. (2011). Using Ecological Theory to Guide Urban Planting Design An adaptation strategy for climate change. Landscape Journal, 30, 173-193.

Idilfitri, S., \& Mohamad, N. H. N. (2012). Role of Ornamental Vegetation for Birds' Habitats in Urban Parks: Case Study FRIM, Malaysia. Procedia - Social and Behavioral Sciences, 68, 894-909.

Irvine, K. N., Devine-Wright, P., Payne, S. R., Fuller, R. A., Painter, B., \& Gaston, K. J. (2009). Green space, soundscape and urban sustainability: an interdisciplinary, empirical study. Local Environment, 14, 155-172.

Jackson, S. L. (2014). Research Methods A Modular Approach (Third).

Johnston, T. D., \& Pietrewicz, A. T. (2014). Issues in the Ecological Study of Learning. New York: Psychology Press.

Madigan, D., Stang, P. E., Berlin, J. A., Schuemie, M., Overhage, J. M., Suchard, M. A., ... Ryan, P. B. (2014). A Systematic Statistical Approach to Evaluating Evidence from Observational Studies. Annual Review of Statistics and Its Application, 1, 11-39. 
McCormack, G. R., Rock, M., Toohey, A. M., \& Hignell, D. (2010). Characteristics of urban parks associated with park use and physical activity: a review of qualitative research. Health \& Place, 16, 712-26.

Mohamad, N. H. N., Idilfitri, S., \& Thani, S. K. S. O. (2013). Biodiversity by Design: The attributes of ornamental plants in urban forest parks. Procedia - Social and Behavioral Sciences, 105, 823-839.

Morgan, J. L., Gergel, S. E., \& Coops, N. C. (2010). Aerial Photography: A Rapidly Evolving Tool for Ecological Management. BioScience, 60, 47-59.

Nagendra, H., \& Gopal, D. (2011). Tree diversity, distribution, history and change in urban parks: studies in Bangalore, India. Urban Ecosystems.

Nielsen, A. B., van den Bosch, M., Maruthaveeran, S., \& van den Bosch, C. K. (2013). Species richness in urban parks and its drivers: A review of empirical evidence. Urban Ecosystems, 16, 1-23.

Niemelä, J. (2014). Ecology of urban green spaces: The way forward in answering major research questions. Landscape and Urban Planning. doi:10.1016/j.landurbplan.2013.07.014

Nisbet, I. C. T. (2013). Seasonal occurrence, migrations and habitat relationships of blue-tailed and blue-throated bee-eaters Merops Philippinus and M. Viridis in Peninsular Malaysia. Raffles Bulletin of Zoology, 219-223.

Nordh, H., Alalouch, C., \& Hartig, T. (2011). Assessing restorative components of small urban parks using conjoint methodology. Urban Forestry \& Urban Greening, 10, 95-103.

Nordh, H., \& Østby, K. (2013). Pocket parks for people - A study of park design and use. Urban Forestry \& Urban Greening, 12, 12-17.

Ostermann, F. O. (2010). Digital representation of park use and visual analysis of visitor activities. Computers, Environment and Urban Systems, 34, $452-464$.

Peris, S., \& Montelongo, T. (2014). Birds and small urban parks: a study in a high plateau city. Turkish Journal of Zoology, 38, 316-325.

Peschardt, K. K., Stigsdotter, U. K., \& Schipperrijn, J. (2014). Identifying Features of Pocket Parks that May Be Related to Health Promoting Use. Landscape Research, 1-16.

Phellas, C. N., Bloch, A., \& Seale, C. (2011). Structured Methods : Interviews, Questionnaires and Observation. In Researching Society and Culture (pp. 181205).

Ren, Z., He, X., Zheng, H., Zhang, D., Yu, X., Shen, G., \& Guo, R. (2013). Estimation of the relationship between urban park characteristics and park cool island intensity by remote sensing data and field measurement. Forests, 4, 868-886.

Rune, F., \& Hels, T. (2004). Udvikling af bynaturindeks (BNI): naturvurdering i Københavns Kommune (Development of Urban Nature Index: Nature Appreciation in Copenhagen). Skov \& Landskab (Forest \& Landscape) University of Copenhagen.

Sandström, U. G., Angelstam, P., \& Mikusiński, G. (2006). Ecological diversity of birds in relation to the structure of urban green space. Landscape and Urban Planning, 77, 39-53.

Sulaiman, S., Mohamad, N. H. N., \& Idilfitri, S. (2013). Contribution of Vegetation in Urban Parks as Habitat for Selective Bird Community. Procedia - Social and Behavioral Sciences, 85, 267-281.

Tse, M. S., Chau, C. K., Choy, Y. S., Tsui, W. K., Chan, C. N., \& Tang, S. K. (2012). Perception of urban park soundscape. The Journal of the Acoustical Society of America, 131, 2762-71.

Tzoulas, K., \& James, P. (2010). Peoples' use of, and concerns about, green space networks: A case study of Birchwood, Warrington New Town, UK. Urban Forestry \& Urban Greening, 9, 121-128. 